agreeing international standards for important aspects of SARS research, such as treatments and diagnostic tests. The latter will be especially important for ruling out SARS when other respiratory diseases occur. "It will be quite a challenge," says Klaus Stöhr, project leader for the WHO's influenza programme.

There are already dozens of tests that can identify the virus that causes SARS, but they are not yet sensitive enough to confirm infection during the early stage when patients may be passing the virus on to others. Some researchers have claimed accuracies as high as $95 \%$ for tests that can be done earlier, but so far "there have been no standards for evaluating the tests", says Christian Drosten, a virologist at the Bernhard Nocht Institute for Tropical Medicine in Hamburg, Germany. And there is surprisingly little agreement on what works and what doesn't. “The diagnostic tests are a real mess right now," says one disgruntled researcher, who didn't want to be identified.

One obstacle is the lack of standardized SARS samples. But the WHO has now persuaded Hong Kong to make samples, including blood and sputum, available at shipping cost to both private and public researchers. Stöhr adds that the WHO is starting to distribute "gold standard" viral samples against which the WHO's collaborating centres can assess the performance of their tests.

But Brundtland and others voiced concern that the WHO's efforts alone cannot keep research momentum going as the number of SARS patients drops off. "The WHO isn't made of money," she says. "Scientists and politicians in individual countries have to continue their efforts."

\title{
Visa rules leave US colleges facing semester of discontent
}

Geoff Brumfiel, Washington

Immigration rules will wreak havoc at US universities when the academic year begins this autumn, administrators are predicting.

The leaders of four groups representing most US university and college administrators - including the Association of American Universities (AAU), which speaks for 50 top research schools - outlined their concerns in a letter to US secretary of state Colin Powell on 17 June.

They warned that visa delays could keep many foreign students and academic staff out of the country, causing "classes to be cancelled, and educational and research opportunities to be lost".

The administrators are particularly worried about an instruction issued by the state department on 21 May, which they fear will dramatically increase the number of visa applicants who must undergo a face-to-face interview with consular officials.

At present, about $40 \%$ of all visa applicants are called in for interview, according to Barry Toiv, a spokesman for the AAU. But under the new instruction, embassies and consulates must interview virtually every applicant aged between 16 and 60 - without any increase in resources. "It will slow down a process that is already very cumbersome," Toiv says.

The instruction will pile more pressure on a system already under great strain, university officials say. Many students and researchers have had their visits to the United States delayed by weeks or months by an interagency review process set up to screen for

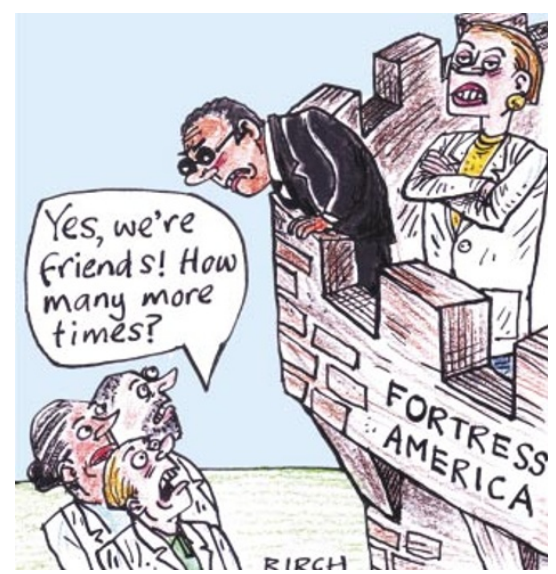

terrorists (see Nature 422, 457-458; 2003).

In addition, a computer database at the Department of Homeland Security, which will track foreign students and visiting scholars, is expected to start working in time for the new academic year, creating more headaches for the universities.

Debra Stewart, president of the Council of Graduate Schools and one of the letter's signatories, predicts that some students and staff will head for other countries such as Britain, France and Australia, in the face of lengthening delays.

State department spokeswoman Brooke Summers says that the agency is working to alleviate the delays. "We're increasing our staff and doing all that we can," she says, adding that the current environment requires extra security in the visa-screening process.

\section{European deal aims to attract Arab scientists}

\section{Nicola Nosengo, Munich}

The European Union (EU) is taking steps to attract more scientists from Arab countries into its Framework programme on research.

Later this week, European research commissioner Philippe Busquin will sign fresh agreements on science and technology cooperation with Morocco and Tunisia. A further agreement with Egypt is likely to be reached during the summer, officials at the European Commission say.

The officials hope that the move will boost Arab science, nurture political dialogue in the Middle East, and fend off criticism that the EU discriminates in favour of Israel.

In theory, scientists anywhere in the world can participate in Framework projects that are led by researchers from nations that are full members of the programme. But scientists in Arab countries are mostly unaware of the opportunity, research administrators say, or may be deterred by the complexity of the application process.

Under the new agreement, researchers in Morocco and Tunisia will be given up-todate contact information for all of the groups taking part in Framework projects, and will get assistance in making applications to join in.

"A strong connection to European research is essential for science in north Africa," says Youssef Alouane, president of the University of Tunis-El Manar, one of Tunisia's leading universities. "We are very pleased with these agreements."

The agreements will be signed just two weeks after Israel's full participation in the Sixth Framework Programme was confirmed. Under an agreement in place since 1998, Israel pays its share of Framework's overall cost and participates fully in the programme.

Maria Kayamanidou, an official at the European Commission, hopes that the new agreements will also boost cooperation between Arab and Israeli researchers. "Israel and the surrounding countries have a strategic interest in cooperating for research," she says. "We try to provide them with a framework to do that."

But some continue to view the agreement with Israel - which includes the Palestinian territories — as discriminatory. "The EU scientific cooperation policy has no significant impact on our region," says Imad Khatib, the Secretary General of the Palestine Academy for Science and Technology. 